\title{
EVALUATION OF THE CHARACTERISTICS AND CLINICAL RESULTS OF THE PATIENTS HOSPITALIZED WITH COVID-19 PNEUMONIA IN THE PROVINCE OF MUS: A STATE HOSPITAL EXPERIENCE
}

\author{
TÜRKIYE'NIN MUŞ ILINDEKI COVID-19 PNÖMONISI NEDENIYLE HASTANEYE \\ YATIRILAN HASTALARIN ÖZELLIKLERI VE KLINIK SONUÇLARININ \\ DEĞERLENDIRILMESI: IKINCI BASAMAK HASTANE DENEYIMI
}

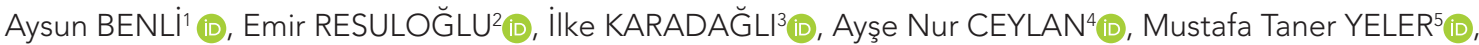
Gürkan DANIŞAN ${ }^{6} \mathbb{D}$, Cihan BÜYÜKSÜTÇÜ7 $\mathbb{D}$, Mehmet BALCI ${ }^{8} \mathbb{D}$, Şinasi KORKMAZ $\mathbb{D}$, Bilal AKDEMIR ${ }^{10} \mathbb{D}$, Adil Akın YILDIRAN ${ }^{11}$ (D), Cemal YAŞAR ${ }^{11}$ (ID

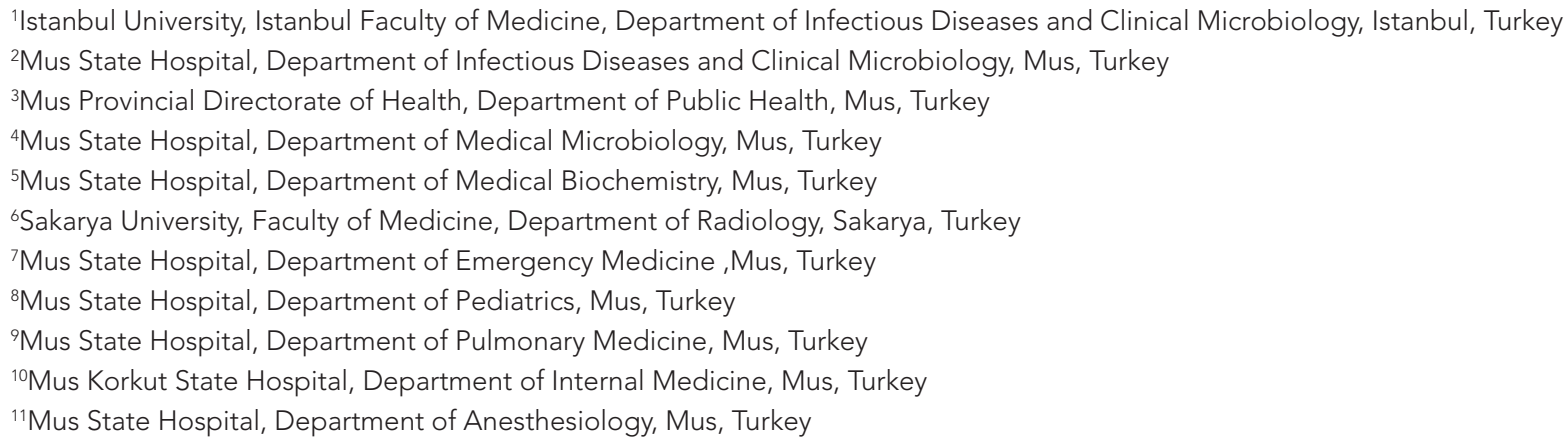

ORCID IDs of the authors: A.B. 0000-0003-0679-0990; E.R. 0000-0002-3274-4878; I.K. 0000-0002-9332-6848; A.N.C. 0000-0002-0049-6873; M.T.Y. 0000-0002-2774-5112; G.D. 0000-0003-2052-0006; C.B. 0000-0001-7987-2669; M.B. 0000-0003-2394-5771; Ş.K. 0000-0003-1135-5555; B.A. 0000-0003-3223-1500; A.A.Y. 0000-0002-4410-5475; C.Y. 0000-0001-7896-0640

Cite this article as: Benli A, Resuloglu E, Karadagli I, Ceylan AN, Yeler MT, Danisan G, et al. Evaluation of the characteristics and clinical results of the patients hospitalized with COVID-19 pneumonia in the province of Mus: a state hospital experience. J Ist Faculty Med 2021;84(2):149-57. doi: 10.26650/IUITFD.2021.812574

\section{ABSTRACT}

Objective: In this study, we aimed to determine the characteristics of COVID-19 pneumonia patients, and also predict factors affecting the severity of the disease.

Methods: This is a retrospective, single-center study. Hospitalized COVID-19 pneumonia patients aged over 18 years between March 19th 2020 , and May $19^{\text {th }} 2020$ were included in the study. The demographic, and clinical characteristics of patients, and factors associated with severe COVID-19 were analyzed. Mul-

\section{ÖZET}

Amaç: Bu çalışmada COVID-19 pnömonili hastalarının özelliklerini ve aynı zamanda hastalığın şiddetini etkileyen faktörleri belirlemeyi amaçladık.

Gereç ve Yöntem: Çalışmamız tek merkezli, retrospektif bir çalışmadır. Çalışmaya 19 Mart - 19 Mayıs 2020 tarihlerinde hastanede yatan, 18 yaş ve üstü, COVID-19 pnömonili hasta dahil edildi. Hastaların demografik, klinik özellikleri ve şiddetli COVID-19 ile ilişkili faktörler analiz edildi. Şiddetli COVID-19'u öngören faktör-

Corresponding author/iletişim kurulacak yazar: aysunb@gmail.com

Submitted/Başvuru: 20.10.2020 • Revision Requested/Revizyon Talebi: 09.12.2020 •

Last Revision Received/Son Revizyon: 10.12.2020 • Accepted/Kabul: 28.12.2020 • Published Online/Online Yayın: 09.03 .2021 
tivariate logistic regression analysis was performed to evaluate the factors predicting the severity of COVID-19.

Results: A total of 228 patients with COVID-19 pneumonia were recorded. The mean age of the patients was $51 \pm 19$ years, and 136 (59.6\%) were men. Of the patients, $47.4 \%$ had at least one comorbidity. Intensive care unit (ICU) admission, and mortality were detected in $29(12.7 \%)$, and in $17(7.5 \%)$ patients respectively. No mortality was detected in non-severe disease. Our results revealed that dyspnea (OR:7.449 95\% Cl 2.444-22.708, $\mathrm{p}<0.001$ ), fatigue (OR:5.968 96\% Cl 2.155-16.526, p:0.001), elevation of LDH (OR: 4.288 95\% Cl 1.109-16.584, p:0.035) and elevation of D-dimer (OR:3.242 95\% Cl 1.106-9.501, p:0.032) levels at admission were major independent predicting factors for severe COVID-19 disease.

Conclusion: Dyspnea, fatigue, elevation of LDH and D-dimer levels are closely related to severe disease in COVID-19. In addition to typical pneumonia signs, fatigue, LDH, and D-dimer can be used as valuable indicators at admission for distinguishing severe COVID-19 pneumonia patients in the early stage. Therefore, this may lead to improved outcomes in patients hospitalized with COVID-19.

Keywords: COVID-19, pneumonia, clinical characteristics, severity, predicting factors leri değerlendirmek için çok değişkenli lojistik regresyon analizi yapıldı.

Bulgular: COVID-19 pnömonisi olan toplam 228 hasta kay-

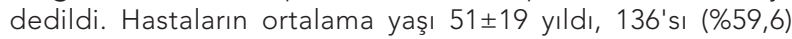
erkekti. Hastaların \%47,4'ünde en az bir komorbidite vardı. Yoğun bakım ünitesine (YBÜ) yatış ve ölüm sırasıyla 29 (\%12,7) ve $17(\% 7,5)$ hastada tespit edildi. Ağır olmayan hastalarda ölüm tespit edilmedi. Başvuru anındaki dispne (OR:7,449 \%95 $\mathrm{Cl} 2,444-22,708, p<0,001)$, halsizlik (OR:5,968\%95 Cl 2,15516,526, p:0,001), LDH yüksekliği (OR:4,288 \%95 Cl 1,10916,584, p:0,035) ve D-dimer yüksekliği (OR:3,242 \%95 Cl 1,106-9,501, p:0,032) şiddetli COVID-19 hastalığı için başlıca bağımsız öngörücü faktörlerdi.

Sonuç: Dispne, halsizlik, LDH ve D-dimer seviyelerinin yükselmesi şiddetli COVID-19 ile yakından ilişkilidir. Tipik pnömoni belirtilerine ek olarak, ağır COVID-19 pnömonili hastaları erken evrede ayırt etmek için başvuru sırasındaki halsizlik, LDH ve D-dimer değerli göstergeler olarak kullanılabilir Başvuruda bu göstergeleri değerlendirmek COVID-19 ile hastaneye yatırılan hastalarda daha iyi sonuçlara yol açabilir.

Anahtar Kelimeler: COVID-19, pnömoni, klinik özellikler, hastalık şiddeti, belirleyici faktörler

\section{INTRODUCTION}

The Coronavirus Disease 2019 (COVID-19) is a respiratory tract disease, whose common symptoms include fever, cough, dyspnea, fatigue and myalgia, which are similar to those of SARS and MERS (1). The World Health Organization (WHO) declared the COVID-19 outbreak caused by the SARS-CoV-2 virus a pandemic on 11 March, 2020 (2). The first COVID-19 case was also detected on 11 March, 2020 in Turkey (3). Starting in Wuhan, Hubei Province, China, the global dissemination rate has accelerated, and community spread is ongoing in many countries and there were 37,326,080 confirmed cases and 1,073,973 deaths worldwide as of August 30th, 2020 (4). The total number of patients in Turkey was 335,533, the total number of deaths reached 8,837 on the same date (5). SARS-CoV-2 can cause mild, moderate, severe or critical COVID-19 symptoms. Although most infections are not severe, patients with severe or critical disease are more common among hospitalized patients. COVID-19 has caused hospitalization, readmission and mortality particularly among older adults, and has become a major public health issue $(6,7)$.

Mus is a small city on the east of Turkey with a population of 408,809 . The city has a second-line hospital. We hospitalized our first COVID-19 patient on March 19th in Mus, and after this date, the number of cases gradually increased. In this clinical study we aimed to evaluate the epidemiological, clinical, laboratory and radiological features of adult COVID-19 patients who were hospitalized in a second-line hospital as well as to determine the risk factors affecting the severity of the disease in patients.

\section{MATERIALS AND METHODS}

\section{Study design and participants}

Our research was designed as a retrospective, descriptive single center study. COVID-19 was diagnosed on the basis of COVID-19 guide by the Turkish Ministry of Health which is updated in the process (first version was published in January 2020 under the title '2019-nCoV Guide') (8). Hospitalized pneumonia cases aged over 18 years between 19.03.2020-19.05.2020 were included in the study. Not all cases were laboratory-confirmed. Some cases were radiologically compatible with COVID-19. Outpatients, asymptomatic patients and radiologically unconfirmed patients were excluded. Written informed consent was waived in light of the urgent need to collect the data. This study was approved by the Ethics Committee of Elazig Firat University (30 June 2020, 2020/10-04).

\section{Data collection}

Researchers collected data from patients' electronic medical records. The epidemiological data, exposure history, symptoms and signs, laboratory results, underlying comorbidities, thorax computerized-tomography (CT) scans, real-time PCR (RT-PCR) detection results, therapies applied for COVID-19, survival data, and length of hospital stay were obtained and recorded in the study forms. Symptoms, signs, laboratory data and thorax CT scans of the patients were collected at admission. 


\section{Study definitions and grading criteria for COVID-19}

A laboratory-confirmed case was defined as a positive result on RT-PCR for the presence of SARS-CoV-2 in both nasal and pharyngeal swab specimens. Measurement of body temperature over the forehead above $37.7^{\circ} \mathrm{C}$ was considered as fever. A lymphocyte count less than 1,000/ $\mu \mathrm{L}$ was evaluated as lymphopenia. People who had close contact with a COVID-19 patient in the last 14 days were considered as exposed patients. Abnormal laboratory results were determined in accordance with the reference ranges in the hospital laboratory. According to WHO COVID-19 guide; patients were divided into three groups as moderate pneumonia, severe pneumonia, and critical disease based on patients' symptoms, signs, laboratory and imaging results at admission (9). Moderate pneumonia is defined as the clinical signs of pneumonia (fever, cough, dyspnea) but no signs of severe pneumonia, including $\mathrm{SpO} 2 \geq 90 \%$ on room air. Severe pneumonia is defined as clinical signs of pneumonia in addition to one of the following: respiratory rate over 30 breaths/min, severe respiratory distress, or $\mathrm{SpO} 2<90 \%$ on room air. COVID-19 patients with acute respiratory distress syndrome (ARDS), sepsis and septic shock were considered as critical patients. Patients with moderate pneumonia were considered as non-severe, patients with severe pneumonia and critical disease were considered as having severe disease in the comparison of patients' data. Thorax CT findings of COVID-19 patients were classified as typical, indeterminate and atypical appearance in accordance with the recommendations of the American College of Radiology (10). All thorax CT scans were re-evaluated by the radiologist and recorded again according to this classification. The mortality was defined as all-cause in-hospital death.

\section{Laboratory confirmation}

Microbiological diagnosis of COVID-19 was performed by both nasal and pharyngeal sampling. Bio-speedy viral nucleic acid buffer (Bioeksen R\&D Technologies Ltd, Turkey) was used for nucleic acid extraction from viral transport media. Bio-Rad CFX Connect RT- PCR detection system (California, USA) device and Bio-speedy COVID-19 RT-PCR detection kit (Bioeksen R\&D Technologies Ltd, Turkey) was used for the RT-PCR process. The kit manufacturer's instructions were followed for the extraction, and PCR processes.

\section{Statistical analysis}

Statistical analyses were performed using the Statistical Package for the Social Sciences (SPSS) 21 (IBM Corp., Armonk, NY, USA). Categorical variables were reported as percentages and compared using the Chi-square test, and the Fisher's Exact test. Continuous variables were presented as means \pm standard deviations (SDs). When measurements were normally distributed, an independent group t-test was used. Otherwise, the Mann-Whit- ney $U$ test was used. A logistic regression was used to explore the predicting factors associated with the severe disease. Categorical variables with $p<0.05$ in univariate analyses were entered into multivariate logistic regression models. Odds ratios and $95 \%$ confidence intervals were calculated for independent variables. A $p$ value of $<0.05$ was considered statistically significant.

\section{RESULTS}

\section{Demographic and clinical characteristics}

Between March 19th 2020 , and May 19th $, 2020,277$ patients were hospitalized with COVID-19, and 228 patients met the inclusion criteria. The mean age of the patients was $51 \pm 19$ years, and $59.6 \%$ were male. The most common symptoms were cough (60.5\%), dyspnea (46.1\%), fatigue (35.1\%) and fever (31.1\%). Of the patients, $28.1 \%$ had a history of contact with a COVID-19 patient, and $15.8 \%$ of the patients had travel history in the last 14 days. One hundred and eight patients (47.4\%) had at least one comorbidity. Hypertension and diabetes mellitus (DM) were the most common comorbidities with a rate of $28.5 \%$, and $15.8 \%$ respectively. One hundred and seventy one of the 228 patients (75\%) had moderate pneumonia, 41 patients (18\%) had severe pneumonia, and 16 patients (7\%) had critical disease. The CURB-65 score of 49 patients (21.5\%) was two and above. Mean age and rate of the patients over 65 years old were higher in severe patient group $(p<0.001)$. In addition, comorbidities of severe patients were significantly higher $(p<0.001)$. The detailed demographic and clinical characteristics and comparison of the patients' data are shown in Table 1.

\section{Laboratory and radiologic findings}

At admission, elevation of CRP (77.6\%), LDH (65.9\%) and D-dimer (48.8\%) levels were the prominent abnormal laboratory parameters in patients. Lymphopenia, thrombocytopenia, anemia, elevation of C-reactive protein (CRP), D-dimer, ferritin, procalcitonin, creatinine, lactate dehydrogenase (LDH) and creatine phophokinase (CPK) were found to be significant in severe disease. The rate of COVID-19 diagnosis with RT-PCR was $44.7 \%$. RT-PCR tests of 145 patients have been performed in our hospital since April $13^{\text {th }}$ 2020. The quantification cycle $(\mathrm{Cq})$ results of 82 patients with positive COVID-19 RT-PCR were also evaluated. No significant difference was found in terms of PCR positivity rate and mean Cq values in the comparison of severe and non-severe patients. Thorax CT was performed for all patients, and $64.9 \%$ had typical thorax CT findings in terms of COVID-19. The remaining patients had atypical and indeterminate thorax CT findings. The detailed laboratory and radiologic findings of the patients are shown in Table 2.

\section{Treatment, prognosis and clinical outcomes}

Hydroxychloroquine (94.3\%) as an antiviral therapy, azithromycin (84.6\%) as an antibiotic therapy, and low-molecu- 
Table 1: Demographic, clinical characteristics and outcomes of the patients with non-severe and severe disease

\begin{tabular}{|c|c|c|c|c|}
\hline & $\begin{array}{l}\text { Total patient } \\
(n=228)\end{array}$ & $\begin{array}{c}\text { Patients with } \\
\text { non-severe disease } \\
(n=171)\end{array}$ & $\begin{array}{l}\text { Patients with } \\
\text { severe disease } \\
\quad(n=57)\end{array}$ & $\begin{array}{c}\mathrm{p} \\
\text { value }\end{array}$ \\
\hline Age (mean $\pm S D)$ & $51.26 \pm 19.60$ & $47.30 \pm 18.85$ & $63.14 \pm 16.99$ & $<0.001$ \\
\hline$\geq 65$ years $(n, \%)$ & 73 (32\%) & $42(24.6 \%)$ & 31 (54.4\%) & $<0.001$ \\
\hline Male gender (n,\%) & $136(59.6 \%)$ & $104(60.8 \%)$ & $32(56.1 \%)$ & 0.533 \\
\hline \multicolumn{5}{|l|}{ Symptoms (n,\%) } \\
\hline Fever & 71 (31.1\%) & $50(29.2 \%)$ & $21(36.8 \%)$ & 0.283 \\
\hline Cough & $138(60.5 \%)$ & 98 (57.3\%) & 40 (70.2\%) & 0.085 \\
\hline Dyspnea & $105(46.1 \%)$ & 62 (36.3\%) & 43 (75.4\%) & $<0.001$ \\
\hline Fatigue & 80 (35.1\%) & 47 (27.5\%) & 33 (57.9\%) & $<0.001$ \\
\hline Myalgia & 29 (12.7\%) & $19(11.1 \%)$ & $10(17.5 \%)$ & 0.207 \\
\hline Sore throat & $22(9.6 \%)$ & $18(10.5 \%)$ & $4(7 \%)$ & 0.437 \\
\hline Headache & $16(7 \%)$ & $16(9.4 \%)$ & 0 & 0.014 \\
\hline Nasal discharge & $5(2.2 \%)$ & $4(2.3 \%)$ & $4(1.8 \%)$ & 1 \\
\hline Diarrhea & $3(1.3 \%)$ & $2(1.2 \%)$ & $1(1.8 \%)$ & 1 \\
\hline Anosmia & 7 (3.1\%) & $6(3.5 \%)$ & $1(1.8 \%)$ & 0.683 \\
\hline Palpitation & $8(3.5 \%)$ & $8(4.7 \%)$ & 0 & 0.206 \\
\hline Confusion & $6(2.6 \%)$ & $4(2.3 \%)$ & $2(3.5 \%)$ & 0.641 \\
\hline Comorbidity (at least one) (n,\%) & $108(47.4 \%)$ & $66(38.6 \%)$ & 42 (73.7\%) & $<0.001$ \\
\hline Hypertension & 65 (28.5\%) & $37(21.6 \%)$ & $28(49.1 \%)$ & $<0.001$ \\
\hline Diabetes mellitus & $36(15.8 \%)$ & $19(11.1 \%)$ & $17(29.8 \%)$ & 0.001 \\
\hline Chronic obstructive pulmonary disease & $31(13.6 \%)$ & 17 (9.9\%) & $14(24.6 \%)$ & $<0.005$ \\
\hline Coronary artery disease & $19(8.3 \%)$ & $13(7.6 \%)$ & $6(10.5 \%)$ & 0.580 \\
\hline Heart failure & $15(6.6 \%)$ & $8(4.7 \%)$ & $7(12.3 \%)$ & 0.062 \\
\hline Asthma & $11(4.8 \%)$ & $9(5.3 \%)$ & $2(3.5 \%)$ & 0.735 \\
\hline Chronic kidney disease & $10(4.4 \%)$ & $3(1.8 \%)$ & $7(12.3 \%)$ & 0.003 \\
\hline Malignancy & $9(3.9 \%)$ & $4(2.3 \%)$ & $5(8.8 \%)$ & 0.045 \\
\hline Obesity & $5(2.2 \%)$ & $2(1.2 \%)$ & $3(5.3 \%)$ & 0.101 \\
\hline Organ transplantation & $1(0.4 \%)$ & $1(0.6 \%)$ & 0 & 1 \\
\hline Other immunosuppressive conditions & $1(0.4 \%)$ & 0 & $1(1.8 \%)$ & 0.250 \\
\hline \multicolumn{5}{|l|}{ CURB-65 (n,\%) } \\
\hline $0-1$ & $179(78.5 \%)$ & $155(90.6 \%)$ & $24(42.1 \%)$ & $<0.001$ \\
\hline$\geq 2$ & 49 (21.5\%) & $16(9.4 \%)$ & $33(57.9 \%)$ & $<0.001$ \\
\hline Close contact with COVID-19 patient $(n, \%)$ & $64(28.1 \%)$ & $44(25.7 \%)$ & $20(35.1 \%)$ & 0.173 \\
\hline Travel history $(n, \%)$ & $26(15.8 \%)$ & $24(14 \%)$ & $12(21 \%)$ & 0.207 \\
\hline $\begin{array}{l}\text { Duration of hospitalization, days } \\
\text { (mean } \pm \text { SD) }\end{array}$ & $7.44 \pm 5.19$ & $5.94 \pm 0.21$ & $11.96 \pm 1.00$ & $<0.001$ \\
\hline Intensive care support ( $\mathrm{n}, \%)$ & $29(12.7 \%)$ & $3(1.8 \%)$ & $26(45.6 \%)$ & $<0.001$ \\
\hline Mechanical ventilation ( $n, \%)$ & $18(7.9 \%)$ & 0 & $18(31.6 \%)$ & $<0.001$ \\
\hline Mortality (n,\%) & $17(7.5 \%)$ & 0 & $17(29.8 \%)$ & $<0.001$ \\
\hline Oxygen support at discharge $(n, \%)$ & $15(7.1 \%)$ & $8(4.7 \%)$ & 7 (17.5\%) & 0.011 \\
\hline
\end{tabular}

lar-weight-heparin (LMWH) (68\%) as a supportive therapy were the most frequently used medical therapies for our hospitalized COVID-19 patients. We used tocilizumab therapy in 6 patients and convalescent plasma therapy in 12 patients. These supportive therapies, favipravir, lopinavir/ritonavir, antibiotics, corticosteroids, LMWH 
Table 2: Laboratory and radiologic findings of the patients with non-severe and severe disease

\begin{tabular}{|c|c|c|c|c|}
\hline & $\begin{array}{l}\text { Total patient } \\
(n=228)\end{array}$ & $\begin{array}{c}\text { Patients with } \\
\text { non-severe disease } \\
(n=171)\end{array}$ & $\begin{array}{l}\text { Patients with } \\
\text { severe disease } \\
\quad(n=57)\end{array}$ & $\begin{array}{c}\mathrm{p} \\
\text { value }\end{array}$ \\
\hline PCR positivity (n, \%) & $102(44.7 \%)$ & 75 (43.9\%) & 27 (47.4\%) & 0.645 \\
\hline Cq value (mean $\pm S D)$ & $32.97 \pm 6.71$ & $32.84 \pm 6.49$ & $33.34 \pm 7.49$ & 0.967 \\
\hline $\begin{array}{l}\text { Neutrophil/lymphocyte ratio (NLR) } \\
\text { (mean } \pm \text { SD) }\end{array}$ & $4.98 \pm 6.11$ & $4.35 \pm 4.87$ & $6.87 \pm 8.62$ & 0.026 \\
\hline \multicolumn{5}{|l|}{ Abnormal laboratory results $(n, \%)$} \\
\hline Leukocyte $>11,000$ cell/ $/ \mu \mathrm{l}$ & 49/228 (21.5\%) & $32(18.7 \%)$ & $17(29.8 \%)$ & 0.077 \\
\hline Neutrophil >7,800 (cell/pl) & $46 / 228(20.2 \%)$ & $30(17.5 \%)$ & $16(28.1 \%)$ & 0.086 \\
\hline 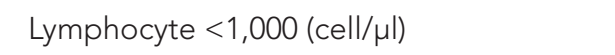 & $46 / 228(20.2 \%)$ & 29 (17\%) & $17(29.8 \%)$ & 0.036 \\
\hline Platelet <142,000 (cell/ul) & $27 / 228(11.8 \%)$ & $14(8.2 \%)$ & $13(22.8 \%)$ & 0.003 \\
\hline $\begin{array}{l}\text { Hemoglobin }<12(\mathrm{~g} / \mathrm{dL}) \text { (female) }<13.5 \text { (g/ } \\
\mathrm{dL} \text { (male) }\end{array}$ & $44 / 228(19.3 \%)$ & $25(14.6 \%)$ & $19(33.3 \%)$ & 0.002 \\
\hline CRP > 5 (mg/L) & $177 / 228(77.6 \%)$ & $125(73.1 \%)$ & $52(91.2 \%)$ & 0.004 \\
\hline D-dimer >500 ( $\mu \mathrm{g} / \mathrm{L})$ & $103 / 211(48.8 \%)$ & $62(40 \%)$ & 41 (73.2\%) & $<0.001$ \\
\hline Ferritin $>322(\mathrm{ng} / \mathrm{mL})$ & $38 / 181$ (21\%) & $20(14.8 \%)$ & $18(39.1 \%)$ & $<0.001$ \\
\hline Procalsitonin >0.50 (ng/mL) & 23/204 (11.3\%) & $10(6.6 \%)$ & $13(24.5 \%)$ & $<0.001$ \\
\hline Fibrinogen >450 (mg/dL) & $11 / 123(8.9 \%)$ & $5(6.1 \%)$ & $6(14.6 \%)$ & 0.118 \\
\hline Creatinine >1.2 (mg/dL) & $27 / 228$ (11.8\%) & $13(7.6 \%)$ & $14(24.6 \%)$ & 0.001 \\
\hline $\mathrm{AST}>40(\mathrm{U} / \mathrm{L})$ & $35 / 228(15.4 \%)$ & 24 (14\%) & $11(19.3 \%)$ & 0.340 \\
\hline $\mathrm{ALT}>41(\mathrm{U} / \mathrm{L})$ & $31 / 228(13.6 \%)$ & $22(12.9 \%)$ & $9(15.8 \%)$ & 0.577 \\
\hline $\mathrm{LDH}>225(\mathrm{U} / \mathrm{L})$ & $149 / 226(65.9 \%)$ & 99 (58.6\%) & 50 (87.7\%) & $<0.001$ \\
\hline CPK >190 (U/L) & $43 / 223(19.3 \%)$ & $26(15.6 \%)$ & $17(30.4 \%)$ & 0.015 \\
\hline Troponin >0.06 (ng/mL) & 10/205 (4.9\%) & $6(4 \%)$ & $4(7.4 \%)$ & 0.315 \\
\hline Triglyceride $>150 \mathrm{mg} / \mathrm{dL}$ & $45 / 160(28.1 \%)$ & $31(26.5 \%)$ & $14(32.6 \%)$ & 0.450 \\
\hline \multicolumn{5}{|l|}{ Classification of thorax CT (n, \%) } \\
\hline Typical & $148(64.9 \%)$ & $107(62.6 \%)$ & $41(71.9 \%)$ & 0.200 \\
\hline Atypical & $30(13.2 \%)$ & $24(14 \%)$ & 65 (10.5\%) & 0.497 \\
\hline Undetermined & $50(21.9 \%)$ & $40(23.4 \%)$ & $10(17.5 \%)$ & 0.355 \\
\hline
\end{tabular}

and dipiridamol were highly used in severe disease $(p<0.05)$. Four patients who had received tocilizumab and five patients who had received convalescent plasma therapy died. Oxygen supportive therapy was required in 76 patients (33.3\%). Twenty nine patients (12.7\%) required intensive care support, 18 (7.9\%) required mechanical ventilation, and 17 (7.5\%) died (Table 1). The mean age of the deceased patients was 72 years. All deceased patients except two had comorbidities. These two patients were aged 73 and 92 years with no previous comorbidities. Fifteen patients (7.1\%) were discharged with oxygen support. Patients with non-severe disease had no hospital-mortality in this study. The detailed medical and supportive therapies of the patients are shown in Table 3.

\section{Multivariate analysis for the disease severity}

In the multivariate analysis, dyspnea (OR:7.449 $(95 \% \mathrm{Cl}$ 2.444-22.708), $p<0.001)$, fatigue (OR:5.968 (95\% Cl 2.15516.526), p:0.001), elevation of LDH (OR:4.228 (95\% Cl 1.109-16.584), p:0.035) and D-dimer (OR:3.442 $(95 \% \mathrm{Cl}$ 1.106-9.501), p:0.032) were found as the predicting factors for severe disease (Table 4).

\section{DISCUSSION}

To our knowledge, this is the first study to evaluate the outcomes of COVID-19 pneumonia in a second-line hospital in Turkey. In the multivariate analysis, dyspnea, fatigue, D-dimer level, and LDH level were the major independent predictors for the disease severity of COVID-19. 
Table 3: Medical and supportive therapies of the patients

\begin{tabular}{lc}
\hline & $\begin{array}{c}\text { Total patient } \\
(\mathbf{n}=\mathbf{2 2 8})\end{array}$ \\
\hline Therapies (n,\%) & \\
\hline Oxygen supportive therapy & $76(33.3 \%)$ \\
Hydroxychloroquine & $215(94.3 \%)$ \\
Favipravir & $48(21.1 \%)$ \\
Lopinavir/ritonavir & $6(2.6 \%)$ \\
Oseltamivir & $72(31.6 \%)$ \\
Azithromycin & $193(84.6 \%)$ \\
Other antibiotics & $54(23.7 \%)$ \\
Tocilizumab & $6(2.6 \%)$ \\
Corticosteroid & $5(2.2 \%)$ \\
Convalescent plasma & $12(5.3 \%)$ \\
Low molecular weight heparin & $155(68 \%)$ \\
Dipiridamol & $27(11.8 \%)$ \\
\hline
\end{tabular}

Both clinical signs, and laboratory parameters have a significant role in predicting disease severity.

The incidence of severe and critically ill patients was higher than the incidence in similarly designed studies (11-13). This can be explained by the fact that, unlike others, mild patients without pneumonia were not included in our study. The ratio of the patients aged over 65 years was also higher than the ratio in previous studies, which scrutinized clinical outcomes of the patients from China and Turkey (11-14). The mean age of the patients and the ratio of the patients' aged over 65 years were found to be significantly higher in patients with severe disease similar to other studies $(11,14,15)$. The disease was more common in men, as in the studies in which hospitalized COVID-19 patients were evaluated $(7,15,16)$.

Cough, dyspnea, and fatigue were prominent symptoms at admission; however, fever (31.1\%) and lymphopenia (20.2\%) were not detected at a high rate unlike other studies (14-16). The reason of the low frequency of fever may be due to previously used antipyretic drugs and also we did not record fever data during hospitalization. Low incidence of lymphopenia can be explained by the genetic factors of the people living in this region and variability of their immune response against the disease. Pollitt et al., indicated in a review that the relationship between genetic susceptibility to SARS-CoV-2 and disease severity was still in its infancy, and further studies may clarify this issue (17). Also, this result may be misleading because only the number of lymphocytes at admission was analyzed.
Table 4: Multivariate analysis of predicting factors for severe disease in COVID-19

\begin{tabular}{|c|c|c|c|}
\hline & $\begin{array}{c}\mathrm{p} \\
\text { value }\end{array}$ & $\begin{array}{l}\text { Odds } \\
\text { ratio }\end{array}$ & $95 \% \mathrm{Cl}$ \\
\hline Age ( $\geq 65$ years) & 0.223 & 2.035 & $0.649-6.378$ \\
\hline Dyspnea & $<0.001$ & 7.449 & $\begin{array}{l}2.444- \\
22.708\end{array}$ \\
\hline Fatigue & 0.001 & 5.968 & $\begin{array}{l}2.155- \\
16.526\end{array}$ \\
\hline Hypertension & 0.154 & 0.388 & $0.106-1.426$ \\
\hline Diabetes mellitus & 0.070 & 3.306 & $0.908-12.036$ \\
\hline $\begin{array}{l}\text { Chronic obstructive } \\
\text { pulmonary disease }\end{array}$ & 0.672 & 1.320 & $0.365-4.776$ \\
\hline $\begin{array}{l}\text { Chronic kidney dis- } \\
\text { ease }\end{array}$ & 0.661 & 1.738 & $0.146-20.622$ \\
\hline Malignancy & 0.451 & 2.782 & $0.195-39.681$ \\
\hline $\begin{array}{l}\text { Lymphocyte <1,000 } \\
\text { (cell/ } / \text { l) }\end{array}$ & 0.917 & 0.941 & $0.301-2.944$ \\
\hline $\begin{array}{l}\text { Platelet }<142,000 \\
(\text { cell/ } / \mu \mathrm{l})\end{array}$ & 0.277 & 2.120 & $0.547-8.222$ \\
\hline $\begin{array}{l}\text { Hemoglobin <12 (g/ } \\
\mathrm{dL} \text { (female), <13.5 (g/ } \\
\mathrm{dL}) \text { (male) }\end{array}$ & 0.187 & 2.213 & $0.681-7.190$ \\
\hline $\mathrm{CRP}>5(\mathrm{mg} / \mathrm{L})$ & 0.540 & 0.646 & $0.160-2.616$ \\
\hline $\begin{array}{l}\text { Procalcitonin }>0.50 \\
(\mathrm{ng} / \mathrm{mL})\end{array}$ & 0.260 & 2.284 & $0.542-9.625$ \\
\hline Ferritin $>322(\mathrm{ng} / \mathrm{mL})$ & 0.307 & 1.855 & $0.567-6.071$ \\
\hline D-dimer $>500(\mu \mathrm{g} / \mathrm{L})$ & 0.032 & 3.242 & $1.106-9.501$ \\
\hline $\begin{array}{l}\text { Creatinine }>1.2(\mathrm{mg} / \\
\mathrm{dL})\end{array}$ & 0.733 & 1.298 & $0.290-5.811$ \\
\hline LD H>225 (U/L) & 0.035 & 4.288 & $\begin{array}{l}1.109- \\
16.584\end{array}$ \\
\hline CPK >190 (U/L) & 0.913 & 1.067 & $0.334-3.404$ \\
\hline
\end{tabular}

Mean duration of hospitalization, comorbidity, dyspnea and fatigue incidence were found to be significantly higher in patients with severe disease $(p<0.001)$. Comorbidity was previously found to be associated with poorer clinical outcomes, and mortality $(11,15,16,18,19)$. The higher incidence of patients with at least one comorbidity may have caused high mortality in this study. In similarly designed studies, mortality was found to be lower. This result was not consistent with our findings. However, this could be due to the fact that they included the patients without pneumonia in their analyses and also the comorbidity rate was lower in these studies $(14,15)$. Hypertension and diabetes mellitus were the leading comorbidities in our study as shown in previous studies, also the frequency of chronic obstructive pulmonary disease (COPD) was higher than all 
of these $(11,13,16,19-22)$. Unlike other studies, the frequency of obesity and malignancy was lower $(7,23-25)$.

The CURB-65 score is a clinical prediction rule that has been validated for predicting mortality in community-acquired pneumonia. In our study, CURB-65 was associated with severe disease in COVID-19. This score was also found to be associated with a poor outcome in COVID-19 pneumonia previously (26). However, the role of this scoring in making the decision of hospitalization is still controversial, therefore further studies are needed (27).

Close contact with a COVID-19 patient was present in $28.1 \%$ of the patients, and household contact was detected in $18.8 \%$ of patients. This data suggests that virus transmission within the family is substantial and that some measures should continue at home throughout the pandemic in suspicion of illness.

Hospital mortality rates in Wuhan, China were between $3.7-28.2 \%$ when the outbreak first emerged $(15,16)$. A report from Italy showed that in-hospital mortality rate was 11.9\% between June and August 2020 (28). The mortality rate was reported as $21 \%$. Also, the mortality in patients receiving mechanical ventilation was reported as $88.1 \%$ in another study involving 5,700 patients in New York, US (7). These studies have significantly higher mortality rates compared with the rates in our study. As we have mentioned before, age and comorbidity are the factors which affect the mortality. Also, unlike the situation in many other countries, the number of cases did not overload the capacity of healthcare services in Turkey and it is still easy to reach medical care.

In a meta-analysis, Henry and et al. summarized laboratory changes in patients with severe or fatal COVID-19 (29). They recommended close monitoring of leukocyte count, lymphocyte count, platelet count, IL-6 and serum ferritin as markers for potential progression to critical illness. Except IL-6 level, we were able to evaluate other biomarkers, and ten of them were found to be significant in severe disease. $\mathrm{LDH}$ level was found as an independent predicting factor for the severity and mortality of COVID-19 previously (30, 31). In addition, researchers indicated that LDH level can be used to monitor the treatment response in COVID-19 pneumonia (32). Fatigue was identified as the prognostic symptom of COVID-19 patients in a study which evaluated 655 laboratory-confirmed COVID-19 cases (33). In addition, dyspnea and elevation of D-dimer were also found as predicting factors in disease severity previously $(23,34-37)$. All of these are similar to our results.

This study has some limitations. Our data was collected retrospectively, and the number of cases was lower. We only collected the clinical characteristics and laboratory data at hospital admission. Changes in laboratory parameters and disease signs during hospitalization were not mentioned in the study. In addition, some patients were discharged with oxygen and LMWH therapy, but we do not have clinical information about the long-term follow-up of these patients.

In conclusion, we summarized the outcomes of the patients with COVID-19 pneumonia in the first two months of the pandemic in Turkey and compared the characteristics of the patients according to disease severity. All current therapies that could be applied to COVID-19 patients in line with the recommendations of the Turkish Ministry of Health were successfully applied in our hospital. Dyspnea, fatigue, increased D-dimer and LDH were found as independent predictors of severe disease in COVID-19 in multivariate analysis. Not only lymphocyte count and D-dimer but also LDH can be used as a valuable indicator for distinguishing severe COVID-19 patients at an early stage, so this may lead to improved outcomes in patients hospitalized with COVID-19. In addition to typical pneumonia symptoms such as cough, fever and dyspnea, fatigue should be questioned in COVID-19 patients. Patients with fatigue should be monitored more closely due to the possibility of severe disease.

Ethics Committee Approval: This study was approved by the Ethical Committe of the Elazig Fırat University (Date:30.06.2020, No:2020/10-04).

Peer Review: Externally peer-reviewed.

Author Contributions: Conception/Design of Study- A.B., E.R., C.B., M.B.; Data Acquisition- A.B., M.T.Y., A.N.C., G.D., C.Y., A.A.Y., Ş.K.; Data Analysis/Interpretation- A.B., i.K.; Drafting Manuscript- A.B., E.R., A.N.C., M.T.Y., M.B.,S.K., B.A.; Critical Revision of Manuscript- A.B., i.K., G.D., C.B., A.A.Y., C.Y.; Final Approval and Accountability- A.B., E.R., I.K., A.N.C., M.T.Y., G.D., C.B., M.B., Ş.K., B.A., A.A.Y., C.Y.

Conflict of Interest: Authors declared no conflict of interest.

Financial Disclosure: Authors declared no financial support.

Etik Komite Onayı: Bu çalışma için etik komite onayı Elazığ Fırat Üniversitesi Etik Kurulu'ndan alınmıştır (Tarih:30.06.2020, Sayı:2020/10-04).

\section{Hakem Değerlendirmesi: Dış bağımsız.}

Yazar Katkıları: Çalışma Konsepti/Tasarım- A.B., E.R., C.B., M.B.; Veri Toplama- A.B., M.T.Y., A.N.C., G.D., C.Y., A.A.Y., Ş.K.; Veri Analizi/Yorumlama- A.B., I.K.; Yazı Taslağı- A.B., E.R., A.N.C., M.T.Y., M.B.,Ş.K., B.A.; İçeriğin Eleştirel İncelemesi- A.B., I.K., G.D., C.B., A.A.Y., C.Y.; Son Onay ve Sorumluluk- A.B., E.R., i.K., A.N.C., M.T.Y., G.D., C.B., M.B., Ş.K., B.A., A.A.Y., C.Y.

Çıkar Çatışması: Yazarlar çıkar çatışması beyan etmemişlerdir.

Finansal Destek: Yazarlar finansal destek beyan etmemişlerdir. 


\section{REFERENCES}

1. Huang $C$, Wang $Y, L i X$, Ren L, Zhao J, Hu Y, et al. Clinical features of patients infected with 2019 novel coronavirus in Wuhan, China. Lancet 2020;395:497-506. [CrossRef]

2. World Health Organization (2020). WHO Director-General's opening remarks at the media briefing on COVID-19 - 11 March 2020 (cited 2020 September 3). https://www.who.int/ director-general/speeches/detail/who-director-general-sopening-remarks-at-the-media-briefing-on-covid-19---11march-2020

3. Fahrettin Koca. Turkey remains firm, calm as first coronavirus case confirmed. Daily Sabah (cited 2020 September 3). https://www.dailysabah.com/turkey/turkey-remains-firmcalm-as-first-coronavirus-case-confirmed/news

4. World Health Organization (2020). WHO Coronavirus Disease (COVID-19) Dashboard (cited 2020 October 12). https://covid19. who.int/?gclid=CjwKCAjw_Y_8BRBiEiwA5 MCBJiyxQ0YP6Vo3QHGiDPb5aJQJvnXF-nboDdGbE9awir ey9LI65CBRiBoC9PoQAvD_BwE

5. T.C. Sağlık Bakanlığı (2020). Türkiye COVID-19 Hasta Tablosu (cited 2020 October 12). https://covid19.saglik.gov.tr

6. Wu Z, McGoogan JM. Characteristics of and Important Lessons From the Coronavirus Disease 2019 (COVID-19) Outbreak in China: Summary of a Report of 72314 Cases From the Chinese Center for Disease Control and Prevention. JAMA 2020;323(13):1239-42. [CrossRef]

7. Richardson S, Hirsch JS, Narasimhan M. Presenting Characteristics, Comorbidities, and Outcomes Among 5700 Patients Hospitalized With COVID-19 in the New York City Area. JAMA 2020;323(20):2052-9.

8. T.C. Sağlık Bakanlığı, Halk Sağlığı Genel Müdürlüğü, COVID-19 (SARS-CoV-2 ENFEKSIYONU) GENEL BILGILER, EPIDEMIOLOJi VE TANI, 29 June 2020 (cited 2020 July 3). Available from: URL: https://covid19.saglik. gov.tr/Eklenti/39060/0/covid19rehberigenelbilgiler epidemiyolojivetanipdf.pdf

9. World Health Organization (2020). Clinical management of COVID-19: Interim guidance (cited 2020 July 3). https://www. who.int/publications/i/item/clinical-management-of-covid-19

10. Simpson S, Kay FU, Abbara S, Bhalla S, Chung JH, Chung $M$, et al. Radiological Society of North America Expert Consensus Statement on Reporting Chest CT Findings Related to COVID-19. Endorsed by the Society of Thoracic Radiology, the American College of Radiology, and RSNA Secondary Publication. J Thorac Imaging 2020;35(4):219-27. [CrossRef]

11. Zhang G, Hu C, Luo L, Fang F, Chen $Y$, Li J, et al. Clinical features and short-term outcomes of 221 patients with COVID-19 in Wuhan, China. J Clin Virol 2020 Apr 9. [CrossRef]

12. Güner R, Hasanoğlu I, Kayaaslan B, Aypak A, Kaya Kalem A, Eser $F$, et al. COVID-19 experience of the major pandemic response center in the capital: Results of the pandemic's first month in Turkey. Turk J Med Sci 2020;50(8):1801-9. [CrossRef]

13. Başaran NÇ, Uyaroğlu OA, Dizman GT, Özişik L, Şahin TK, Taş Z, et al. Outcome of Non-Critical COVID-19 Patients with Early Hospitalization and Early Antiviral Treatment Outside the ICU. Turk J Med Sci 2020 Jul 28. [CrossRef]

14. Guan W, Ni Z, Hu Y, Liang W, Ou C, He J, et al. Clinical characteristics of coronavirus disease 2019 in China. N Engl J Med 2020 Feb 28. [CrossRef]
15. Zhang J, Wang X, Jia X, Li J, Hu K, Chen G, et al. Risk factors for disease severity, unimprovement, and mortality in COVID-19 patients in Wuhan, China. Clin Microbiol Infect 2020;26(6):767-72. [CrossRef]

16. Zhou F, Yu T, Du R, Fan G, Liu Y, Liu Z, et al. Clinical course and risk factors for mortality of adult inpatients with COVID-19 in Wuhan, China: a retrospective cohort study. Lancet 2020;395:1054-62. [CrossRef]

17. Pollitt KJG, Peccia J, Ko Al, Kaminski N, Cruz CSD, Nebert DW, et al. COVID-19 vulnerability: the potential impact of genetic susceptibility and airborne transmission. Human Genomics 2020 May 12. [CrossRef]

18. Guan W, Liang W, Zhao Y, Liang H, Chen Z, Li Y, et al. Comorbidity and its impact on 1590 patients with COVID-19 in China: a nationwide analysis. Eur Respir J 2020 May 14. [CrossRef]

19. Xu PP, Tian RH, Luo S, Zu ZY, Fan B, Wang XM, et al. Risk factors for adverse clinical outcomes with COVID-19 in China: a multicenter, retrospective, observational study. Theranostics 2020;10(14): 6372-83. [CrossRef]

20. Cummings MJ, Baldwin MR, Abrams D, Jacobson SD, Meyer BJ, Balough EM, et al. Epidemiology, clinical course, and outcomes of critically ill adults with COVID-19 in New York City: a prospective cohort study. Lancet 2020;395:176370. [CrossRef]

21. Karakoç ZÇ, Pınarbaşı-Şimşek B, Asil R, Dodurgalı R, Calışkaner F, Özsarı A, et al. First wave in COVID-19 pandemic: A single center experience. Klimik Dergisi 2020;33(3):223-9. [CrossRef]

22. Sümer Ş, Ural $O$, Aktuğ-Demir N, Çifci Ş, Türkseven B, Kılınçer $A$, et al. Clinical and laboratory characteristics of COVID-19 cases followed in Selçuk University Faculty of Medicine. Klimik Dergisi 2020;33(2):122-7. [CrossRef]

23. Gold JAW, Wong KK, Szablewski CM, Patel PR, Rossow J, Silva J, et al. Characteristics and Clinical Outcomes of Adult Patients Hospitalized with COVID-19 - Georgia, March 2020. MMWR Morb Mortal Wkly Rep 2020 May 8 [CrossRef]

24. Grasselli G, Zangrillo A, Zanella A, Antonelli M, Cabrini L, Castelli A, et al. Baseline Characteristics and Outcomes of 1591 Patients Infected With SARS-CoV-2 Admitted to ICUs of the Lombardy Region, Italy. JAMA 2020;323(16):1574-81. [CrossRef]

25. Özger HS, Yıldız PA, Gaygısız Ü, Dikmen AU, Gülmez $Z D$, Y I ldı $M$, et al. The factors predicting pneumonia in COVID-19 patients: preliminary results of a university hospital in Turkey. Turk J Med Sci 2020;50(8):1810-6. [CrossRef]

26. Tomlins J, Hamilton F, Gunning S, Sheehy C, Moran E et al. Clinical features of 95 sequential hospitalised patients] with novel coronavirus 2019 disease (COVID-19), the first UK cohort. J Infect 2020 Aug 8. [CrossRef]

27. Nguyen Y, Corre F, Honsel V, Curac S, Zarrouk V, Fantin B, et al. Applicability of the CURB-65 pneumonia severity score for outpatient treatment of COVID-19. J Infect 2020 Sep. [CrossRef]

28. Characteristics of SARS-CoV-2 patients dying in Italy Report based on available data on October 4th, 2020 (cited 2020 October 6). https://www.epicentro.iss.it/en/coronavirus/ bollettino/Report-COVID-2019_4_october_2020.pdf 
29. Henry BM, Oliveira MHS, Benoit S, Plebani M, Lippi G. Hematologic, biochemical and immune biomarker abnormalities associated with severe illness and mortality in coronavirus disease 2019 (COVID-19): a meta-analysis. Clin Chem Lab Med 2020;58(7):1021-8. [CrossRef]

30. Han Y, Zhang H, Mu S, Wei W, Jin C, Tong C, et al. Lactate dehydrogenase, an independent risk factor of severe COVID-19 patients: a retrospective and observational study. Aging 2020;12(12):11245-58. [CrossRef]

31. Henry BM, Aggarwal G, Wong J, Benoit S, Vikse J, Plebani $M$, et al. Lactate dehydrogenase levels predict coronavirus disease 2019 (COVID-19) severity and mortality: A pooled analysis. Am J Emerg Med 2020;38(9):1722-6. [CrossRef]

32. Wu M, Yao L, Wang $Y$, Zhu $X$, Wang $X$, Tang $P$, et al. Clinical evaluation of potential usefulness of serum lactate dehydrogenase (LDH) in 2019 novel coronavirus (COVID-19) pneumonia. Respir Res 2020 Jul 6. [CrossRef]

33. Li J, Chen Z, Nie Y, Ma Y, Guo Q, Dai X, et al. Identification of Symptoms Prognostic of COVID-19 Severity: Multivariate Data Analysis of a Case Series in Henan Province. J Med Internet Res 2020 Jun 30. [CrossRef]
34. Jain V, Yuan J. Predictive symptoms and comorbidities for severe COVID-19 and intensive care unit admission: a systematic review and meta-analysis. Int J Public Health 2020 May 25. [CrossRef]

35. Hu C, Su F, Dai J, Lu S, Wu L, Chen D, et al. Prediction Model of Severe Coronavirus Disease 2019 (COVID-19) Cases Shows the Leading Risk Factor of Hypocalcemia. Research Square 2020 Jul 14. [CrossRef]

36. Rod JE, Trespalacios OO, Ramirez JC. A brief-review of the risk factors for covid-19 severity. Rev Saude Publica. 2020;54:60. [CrossRef]

37. Yao Y, Cao J, Wang Q, Shi Q, Liu K, Luo Z, et al. D-dimer as a biomarker for disease severity and mortality in COVID-19 patients: A case control study. J Intensive Care 2020 Jul 10. [CrossRef] 